\title{
A SINGLE LC TANK BASED ACTIVE VOLTAGE BALANCING CIRCUIT FOR BATTERY MANAGEMENT SYSTEM
}

\author{
A K M Ahasan Habib, S. M. A. Motakabber*, Muhammad Ibn. Ibrahimy \\ AND A. H. M. Zahirul Alam \\ Dept. of Electrical and Computer Engineering, Faculty of Engineering, International Islamic \\ University Malaysia, Jalan Gombak, 53100 Kuala Lumpur, Malaysia \\ *Corresponding author: amotakabber@iium.edu.my
}

(Received: $19^{\text {th }}$ Feb 2018; Accepted: $23^{\text {rd }}$ May 2018; Published on-line: $1^{\text {st }}$ June 2018)

https://doi.org/10.31436/iiumej.v19i1.895

\begin{abstract}
Nowadays, Battery operated vehicles and power tools are becoming popular due to their simple construction, compact structure, low operating and maintenance cost, moreover renewable energy utilization facility. A single series resonant active converter has been designed to balance the voltage level of electrical energy storage device (ESD). To obtain the necessary operating voltage and current, many electric cells are combined together in series and parallel. A series battery balancing circuit can be used to improve the efficiency of each cell charging and discharging process and consequently increase the lifespan of the battery. A battery management system (BMS) needs an efficient balancing circuit. This paper presents a high-speed single LC-tank DC to DC converter for electric cell balancing scheme. In this research, two $2 \mathrm{~s}$ LiPo battery has been used as energy storage device. The proposed voltage balancing circuit works by charging and discharging the charge storage device through a single series LC-tank circuit. Experimental results show that the proposed balancing circuit can make 0 voltage difference from $800 \mathrm{mV}$, in 285 seconds and it is less time than the current system.
\end{abstract}

ABSTRAK: Satu pengubah resonan sesiri telah direka bagi mengimbangi aras voltan pada kenderaan beroperasikan bateri dan pada mesin jana kuasa yang menjadi semakin popular. Ini kerana strukturnya yang mudah dan kompak, kos operasi dan penyelenggaraan yang rendah, termasuk kemudahan penggunaan tenaga kitar semula dan sebagainya. Bagi mendapatkan voltan dan arus operasi yang sesuai, banyak sel elektrik telah digabungkan bersama dalam gabungan sesiri dan selari. Litar pengimbang bateri sesiri boleh digunakan bagi meningkatkan kecekapan setiap proses pengecasan dan penyahcas sel dan sekaligus meningkatkan jangka hayat sel. Sistem pengurusan bateri (BMS) memerlukan litar pengimbang yang cekap. Kertas ini membentangkan tentang satu pengubah DC-DC tangki-LC berkelajuan tinggi berdasarkan skim pengimbang sel elektrik. Oleh kerana supercapacitors bertindak seperti bateri boleh cas semula; penyelidikan ini telah mengguna pakai dua super-kapasitor dan bukan bateri boleh cas semula. Baki voltan telah dikekalkan dengan mengecas dan menyahcas super-kapasitor menggunakan satu litar tangki-LC. Dengan ini, masa pengimbang keseluruhan voltan dapat dikurangkan dan kecekapan litar dapat ditingkatkan. Hasil eksperimen menunjukkan litar pengimbang yang dicadangkan dapat mengurangkan perbezaan voltan antara dua super-kapasitor dari $350 \mathrm{mV}$ kepada 0 $\mathrm{V}$ dalam tempoh 284 saat, kurang daripada masa sistem sedia ada.

KEYWORDS: Voltage Balancing; Battery Management System; Electrical Energy Storage Device; Resonant Converters; Electric Vehicles. 


\section{INTRODUCTION}

The EVs (electric vehicles) are becoming an important field of business interest in the automobile industries, because of the high price of fossil fuel, economic and ecological issues [1]. In the transportation sector, EVs becoming emerging technology instead of conventional fossil fuel engine. It has proven, that many industries and combustion engines produce $\mathrm{CO} 2, \mathrm{CO}, \mathrm{NO}$, etc. which is the main source of the greenhouse effect. EVs would be solving the environmental and fuel energy issues that are correlated with zero-carbon emission policies. Since most of the vehicles are using fossil fuel and producing huge amounts of $\mathrm{CO}, \mathrm{CO} 2$ and others gas. The renewable energy sources are environmentfriendly, electricity can be generated by using this energy sources. Electric vehicles (EVs) use electricity without emitting the $\mathrm{CO}, \mathrm{CO} 2$ and other gases, which will help in solving environmental and energy issues. The rechargeable battery and supercapacitor i.e., ESD (Energy Storage Device) provides continuous electrical power in electric motors to operate an EV. The ESD such as supercapacitors or batteries are playing a vital part in the hybrid electric vehicle (HEV), plug-in HEV and EV to microgrid [2-4]. Becouse, some small urban city and rural area are started to produce electricity by utilizing the renewable energy sources. They extracted the generated electricity by using microgrid system and charges their HEV and EV battery from the microgrid. Nowadays, Li-ion (Lithium-ion) and LiPo (Lithium Polymer) battery are widely used in EV and portable power equipment due to its high-power capacity, high energy density, low memory effect, low self-discharge, lowtemperature impact, long life cycle etc. [5]. The voltage of a Li-ion/LiPo cell is relatively low. So, for a required load voltage and current, it is connected in series and parallel arrangement. EVs and many systems use rechargeable battery packs such as Li-ion, Lipo, NiCd etc. A battery pack is made by using many unit cells. The battery pack is charged and discharge during application, however at this time there is no guarantee, that each unit cell can be equally charged and equally discharge. As a result, few unit cells of the battery pack may be damaged within a short time and make the whole battery pack imbalance and useless. So, this is a big issue for using a rechargeable battery pack, when the pack is made by many unit cells. The manufacturers make the only unit cell and the users make their own customized size battery pack by using required numbers of the unit cell. In a battery pack, Li-ion/LiPo cells have some drawback, due to different manufacturing, environmental condition and purpose of using. When cells are overcharged then have a chance of the explosion, similarly, undercharged cell reduces its lifetime [6]. For an unbalance charging and discharging affect the capacity and efficiency of a cell is gradually reduced inside the battery pack [7-8].

The cell capacity, input/output current, balancing etc. issues can be overcome by using a battery management system (BMS). The researchers are still working on battery charge balancing to improve battery cell performance $[2,9-10]$. There are two types of battery charge balancing methods are used; namely, passive balancing method and active balancing method. In passive charge balancing method uses a resistor. As a result, the excess charge of the higher energy cell is dissipated by the resistor in the form of heat and to make a balance with the weaker cell. On the other hand, in the active charge balancing method, the excess charge from the higher energy cell is transferred to the lower energy cell through the inductor, capacitor, and transistor [8, 11-12].

In this paper, a single resonant LC-tank converter based cell to cell active balancing circuit has been proposed. The switching frequency of this circuit has been chosen same as the resonant frequency of the LC-tank circuit, so that, the charging or discharging time of the resonant can just to run half period of the resonant frequency. The proposed circuit uses 
fewer numbers of components which, makes the circuit simple, compact, faster and inexpensive.

\section{PROPOSED BALANCING CIRCUIT AND ALGORITHM}

The proposed single LC resonant balancing circuit is shown in Fig. 1. In this circuit, $n$ numbers of ESD are connected in series. The ESD-1 and ESD-n are associated with two MOSFET switches, similarly, ESD-2 and ESD-(n-1) are associated with anti-series MOSFET switches. All the MOSFET switches are operated by a PWM signal. The resonant converter based circuit is worked as an active balancing circuit. To measure the cell voltage, a voltage status monitoring sensor has been used. Each cell voltage of the battery is measured by using a voltage sensor and sends the information to a microcontroller as shown in Fig. 1.

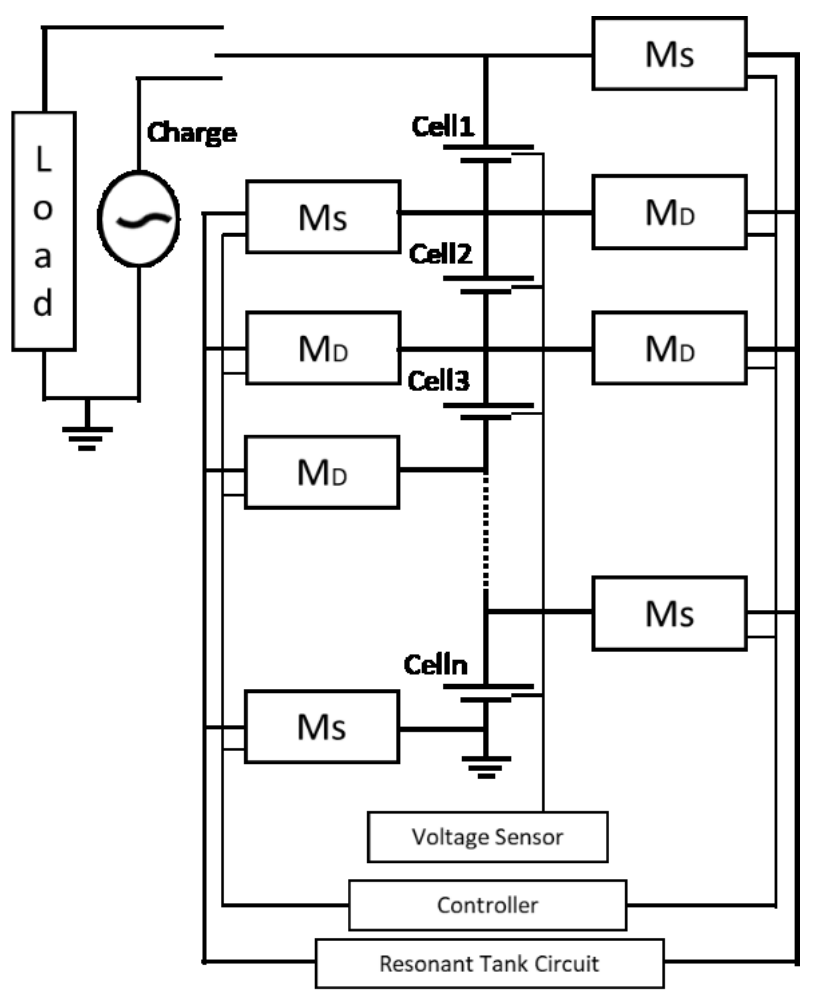

Fig.1: A basic block diagram of the proposed voltage balancing circuit.

The proposed voltage balancing algorithm steps as follows:

1. System initialization

2. Check the cell status by monitoring the sensor voltage

3. Send the cell status to the microcontroller.

If the cell voltages are equal: then

goto step 2

Else: cell voltages are not equal

goto step 4

4. Estimate the cell voltage and find out the highest and lowest voltage cells. 
5. Execute the highest and lowest cell voltage and goto step 4.

6. goto step 2

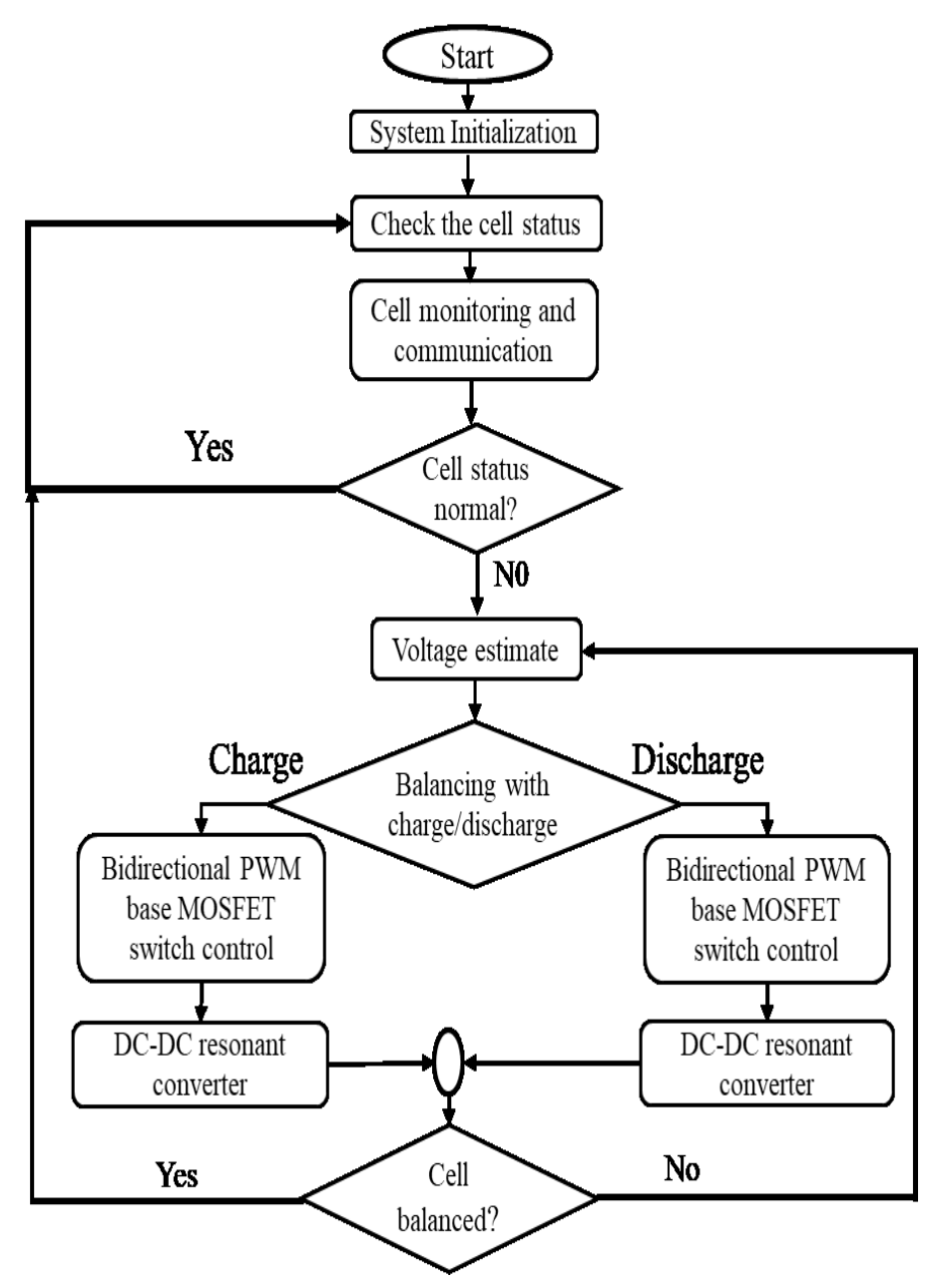

Fig. 2: Flowchart of the proposed voltage balancing algorithm

\section{VOLTAGE BALANCING CIRCUIT WORKING PRINCIPLE}

Figure 3 shows a single resonant LC-tank converter based voltage balancing circuit and its working principle. The associated MOSFET switches and the resonant tank are the basic balancing unit of this circuit. In this circuit, $n$-numbers of the cell are connected in series. Initially, assume that the voltage of Cell-1 is higher than the voltage of Cell-2. During the balancing time, each cell goes through charge and discharge states.

\subsection{Working Mode I: Cell-1 voltage $>$ Cell-2 voltage}

Charging state: in this state, all associate MOSFET switches $\left(M_{\mathrm{S}}\right)$ of Cell-1 are ON state and all associated MOSFET switches $\left(M_{\mathrm{D}}\right)$ of Cell-2 are OFF state. So, the Cell-1, MOSFET switches $\left(M_{\mathrm{S}}\right)$ and LC-tank circuit from a closed loop, and current flows in the loop in the clockwise direction as shown in Fig. 3(a). This time, the LC-tank circuit is stored energy by the Cell-1.

Discharging state: in this state, all associate MOSFET switches $\left(M_{\mathrm{S}}\right)$ of cell-1 are OFF condition and all associate MOSFET switches $\left(M_{\mathrm{D}}\right)$ of cell-2 are ON condition. So, the 
Cell-2, MOSFET switches $\left(M_{\mathrm{D}}\right)$ and the LC-tank circuit from a closed loop, and the current flows in the loop in the counter-clockwise direction as shown in Fig. 3(b). In this situation, Cell-2 is charged by the stored energy of the LC-tank circuit.

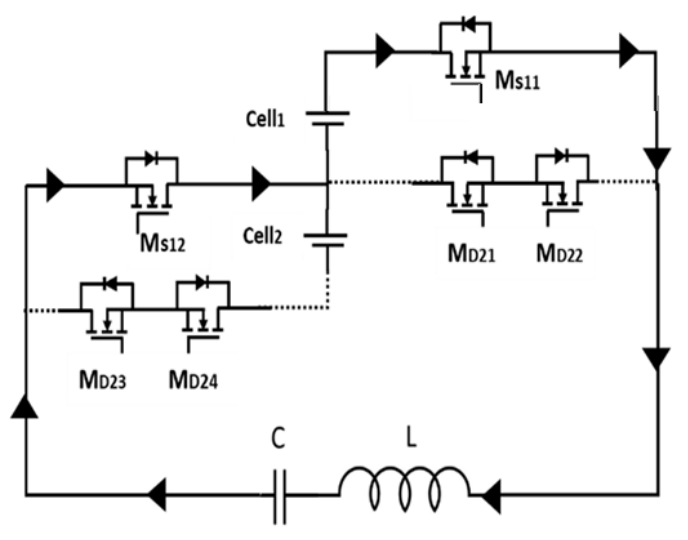

(a)

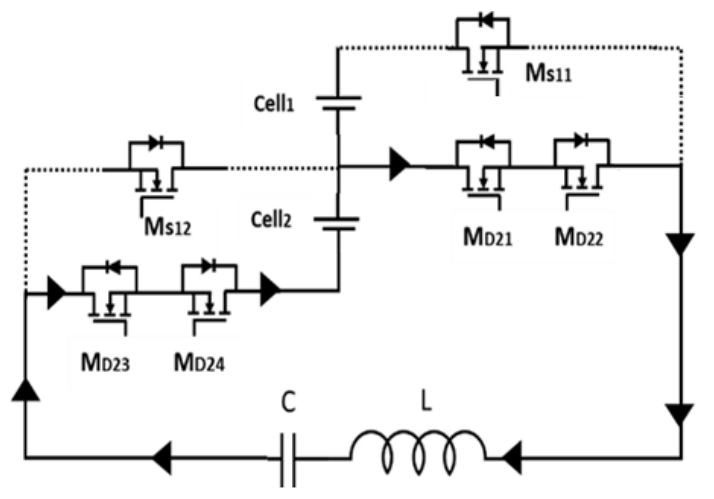

(c)

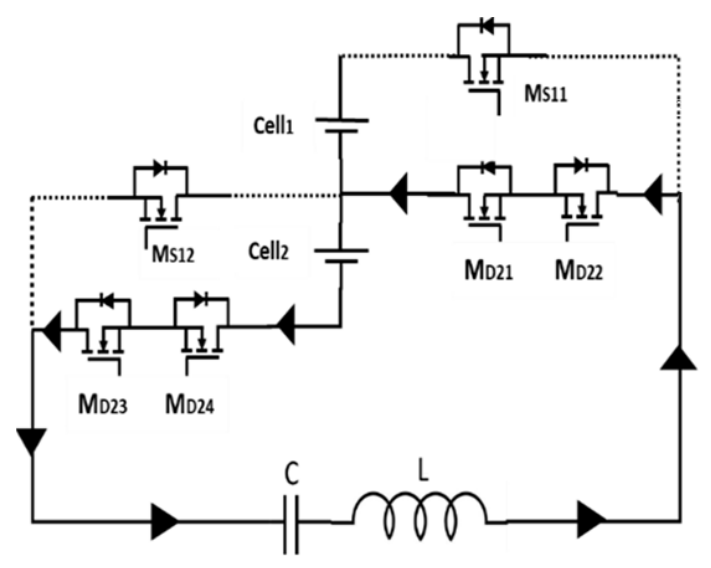

(b)

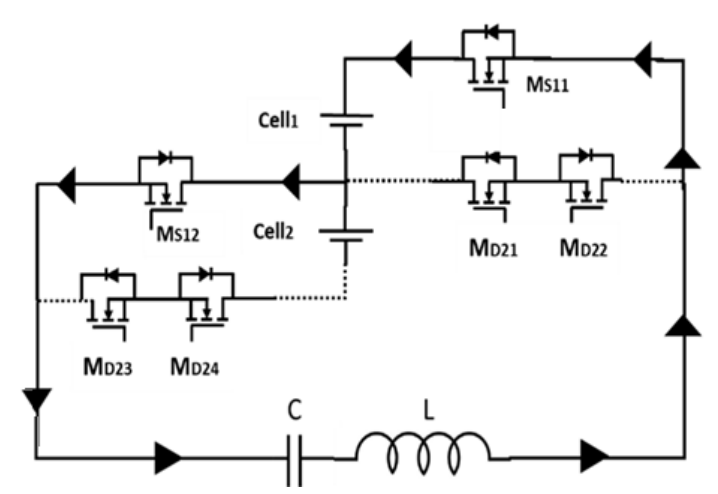

(d)

Fig. 3: Voltage balancing process of the proposed circuit.

\subsection{Working Mode II: Cell-2 voltage $>$ Cell-1 voltage}

In this mode, charging and discharging are just opposite of the working Mode I, as shown in Fig. 3 (c) and 3(d).

For controlling the MOSFET switches a PWM signal has been used as shown in Fig. 4(a). An excess charge of the higher potential cell is transferred to the lower potential cell via a single series resonant LC-tank circuit as shown in Fig. 4(a) and (b). The MOSFET switches are turned $\mathrm{ON}$ and OFF by the high and low voltages of the PWM signal respectively. The analysis of the circuit has been performed casewise based on the voltage condition of $\mathrm{V}_{\text {Cell-1 }}>\mathrm{V}_{\text {Cell-2. }}$.

Case 1: The MOSFET switches $M_{\mathrm{S}}$ are ON and $M_{\mathrm{D}}$ are OFF states, the series LC-tank circuit is connected with the Cell-1 and makes a closed loop as shown in Fig. 4(b). The Cell-1 starts to discharge through the LC-tank circuit and store the energy in the tank circuit. 


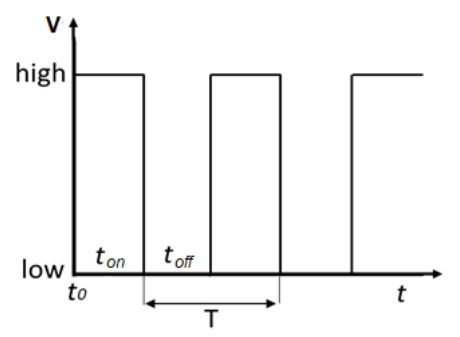

(a)

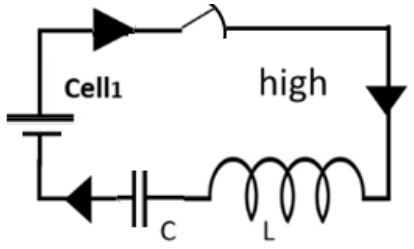

(b)

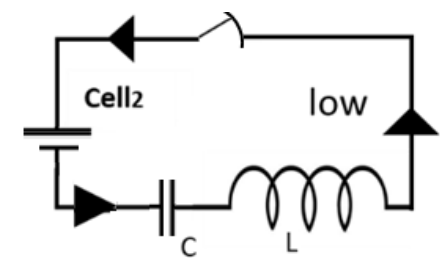

(c)

Fig. 4: Equivalent circuit $\mathrm{V}_{\text {Cell-1 }}>\mathrm{V}_{\text {Cell-2 }}$

The voltage of the Cell-1 can be expressed as (1),

$$
V_{\text {Cell }_{1}}=R_{\text {Cell }_{1}}\left[-i_{\text {Cell }_{1}}(t)+L_{r} \frac{d\left[-i_{\text {Cell }_{1}}(t)\right]}{d t}+R_{c_{r}}\left[-i_{c_{r}}(t)\right]\right.
$$

Where, $R_{\mathrm{Cell}_{1}}$ is the internal resistance of the Cell-1. The current in the LC-tank can be expressed as (2),

$$
i_{L_{r}}(t)=\frac{V_{\text {Cell }_{1}}}{R_{\text {Cell }_{1}}}-\frac{V_{\text {Cell }_{1}}}{R_{\text {Cell }}} e^{\frac{R_{\text {Cell }} R_{C_{r}}}{L C}\left(t-t_{0}\right)}
$$

Where, $i_{L_{r}}\left(t_{0}\right)$ is the initial current, which increases by the switching time $t$.

Case 2: The MOSFET switches, $M_{\mathrm{S}}$ are OFF and $M_{\mathrm{D}}$ are ON states, the series LC-tank circuit is connected with the Cell-2 and makes a closed loop as shown in Fig. 4(c). The $L C$ tank circuit releases its stored energy into the Cell-2. The voltage of the Cell-2 can be expressed as (3),

$$
V_{\text {Cell }_{2}}=-i_{v_{\text {cell } 1}}(t) R_{\text {Cell }_{2}}+V_{L C}(t)
$$

Where, the $L C$-tank circuit voltage $V_{L C}(t)$ can be expressed as (4),

$$
V_{L C}(t)=L C \frac{d^{2} V_{C}(t)}{d t^{2}}+V_{C e l l_{1}}(t)
$$

The PWM signal allows for continuous voltage balance through the LC-tank circuit. The duty cycle and pulse timing of the PWM signal relation can be expressed as (5),

$$
i_{L} D T-i_{L}(1-D) T=0
$$

Where, $D$ is the duty cycle and $T$ is the switching time as shown in Fig.4(a).

\section{Result and Discussion}

A DC to DC converter based active voltage balancing circuit simulation has been established by using MATLAB SIMULINK. A hardware prototyping has been developed to verify the design and effectiveness of the proposed voltage balancing circuit (as Fig. 5.). In this experiment, two $2 \mathrm{~s} \mathrm{LiPo} \mathrm{(lithium} \mathrm{polymer)} \mathrm{battery} \mathrm{has} \mathrm{been} \mathrm{used,} \mathrm{each} \mathrm{battery} \mathrm{pack}$ has $1500 \mathrm{mAh}$ capacity at 7.5V. For experimental setup, initially, the LiPo batteries have been made imbalance charge, which makes the battery voltages as $7.8 \mathrm{~V}$ and $8.4 \mathrm{~V}$ 
respectively. The PWM signal has been generated by using an Arduino microcontroller, which makes it easy to control the switching frequency and duty cycle.

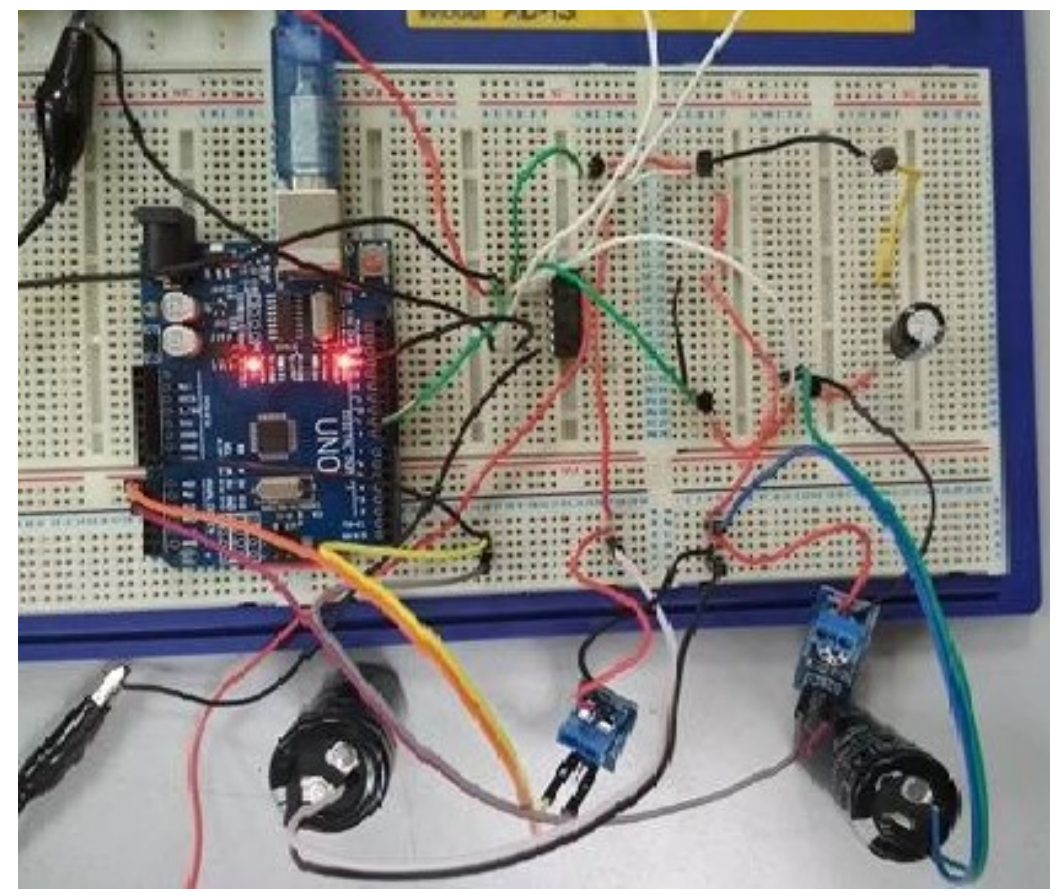

Fig. 5: Experimental setup of the proposed active voltage balancing circuit

The main hardware components used in this experiment are listed in Table 1

Table 1: Components and their values

\begin{tabular}{ll}
\hline Component & Value \\
\hline Arduino microcontroller & UNO R3 \\
2s LiPo battery & $1500 \mathrm{mAh}, 7.5 \mathrm{~V}$ \\
MOSFET switches & $2 \mathrm{~N} 7000$ (nMOS) \\
Inductor & $100 \mathrm{uH}$ (SDR0403- BOURNS) \\
Capacitor & $220 \mathrm{uF}$ \\
\hline
\end{tabular}

Figure 6 shows the $\mathrm{M}_{\mathrm{S}}$ and $\mathrm{M}_{\mathrm{D}}$ gate voltage signals, LC-tank inductor current and capacitor voltage. It is observed that when the switching frequency $(f s)$ and resonant frequency $\left(f_{r}\right)$ are same maximum energy has been stored in and released from the series LC-tank circuit. Fig. 7 shows the charging and discharging effect of the LC circuit when the switching frequency is double of the resonant frequency. In this case, the inductor magnetizing current is not enough to achieve the soft switching and it occurs additional voltage stress in the switch. As a result, the circuit takes a long time for balancing the cell voltage. 

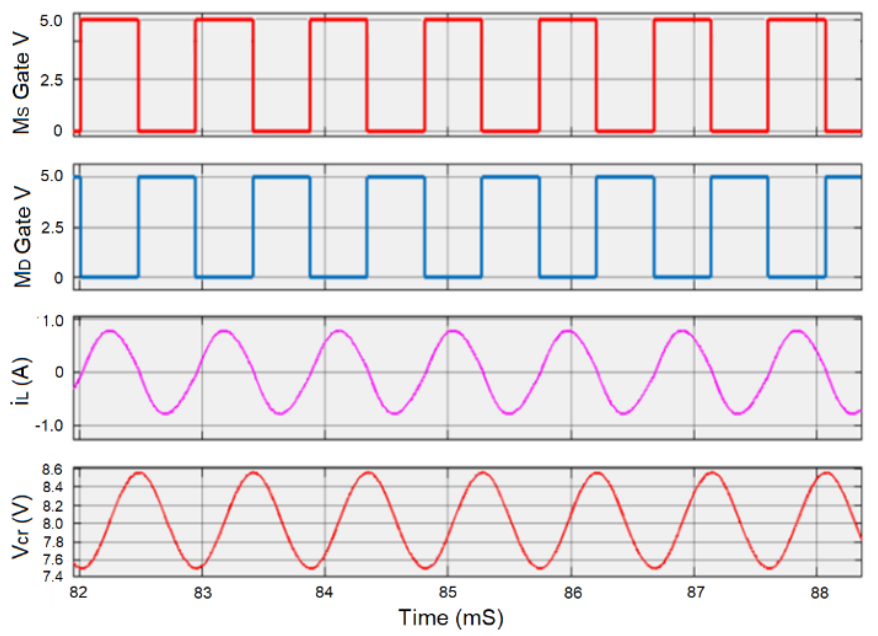

Fig. 6: Simulation result waveforms with an internal resistor (when, $f_{s}=f_{r}$ ).
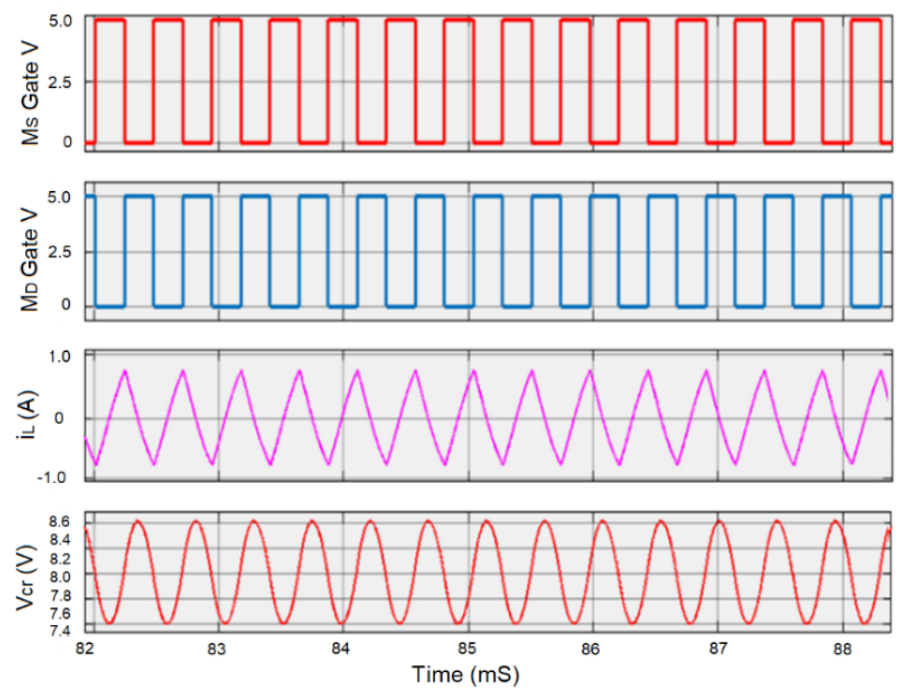

Fig. 7: Simulation result waveforms with an internal resistor (when, $f_{s}=2 f_{r}$ ).

Figure 8 shows the voltage balancing results. Initially, the voltage difference between the two $2 \mathrm{~s}$ LiPo batteries was $800 \mathrm{mV}$. The voltage difference reduced to $0 \mathrm{mV}$ about 275 seconds by the operation of the balancing circuit.
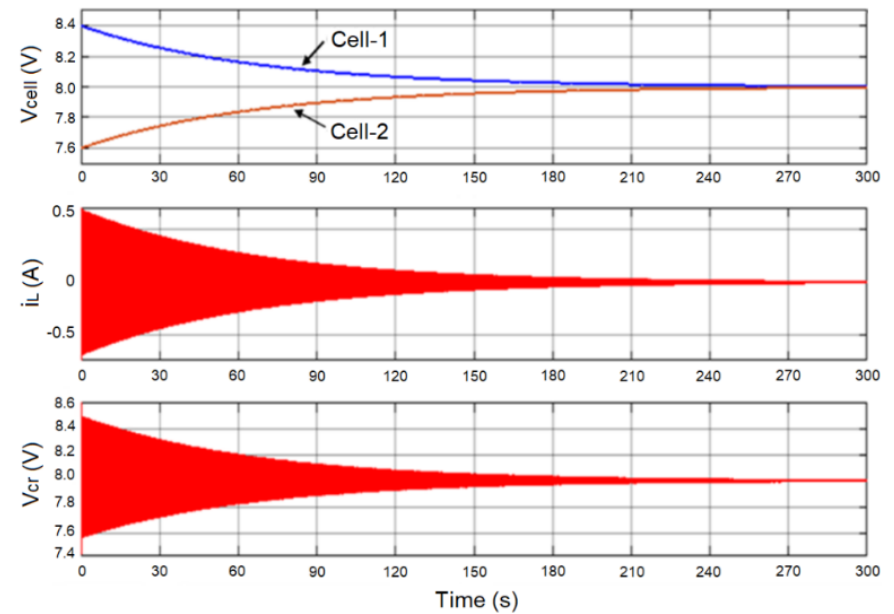

Fig. 8: Simulation results of the two 2s LiPo battery voltage balancing scheme. 
Figure 9 illustrated the experimental circuit gate drive signal, LC-tank inductor current and capacitor voltage waveforms. The two $2 \mathrm{~s}$ LiPo batteries voltage balancing is shown in Fig. 10. The initial voltage difference of the two $2 \mathrm{~s}$ LiPo batteries was $800 \mathrm{mV}$ and after $285 \mathrm{~s}$ this voltage difference developed to $0 \mathrm{~V}$, which is 10 seconds higher than the simulation results.

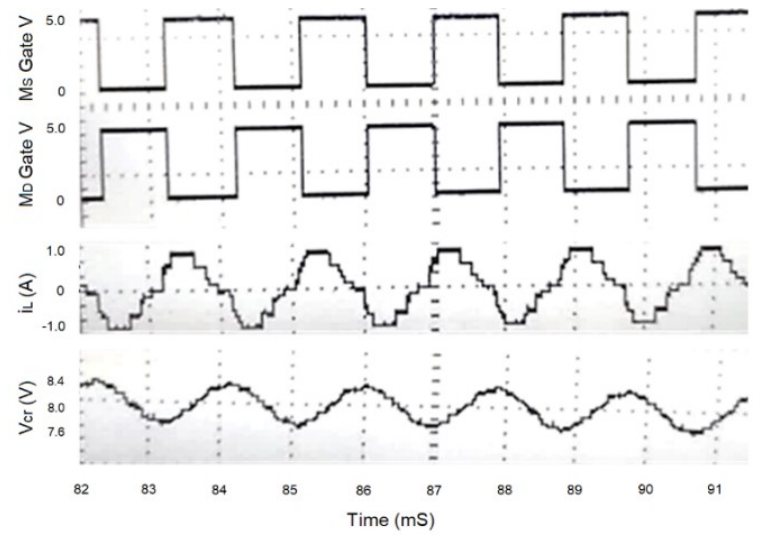

Fig. 9: Gate driving signal, inductor current and capacitor voltage waveforms of the experimental circuit.

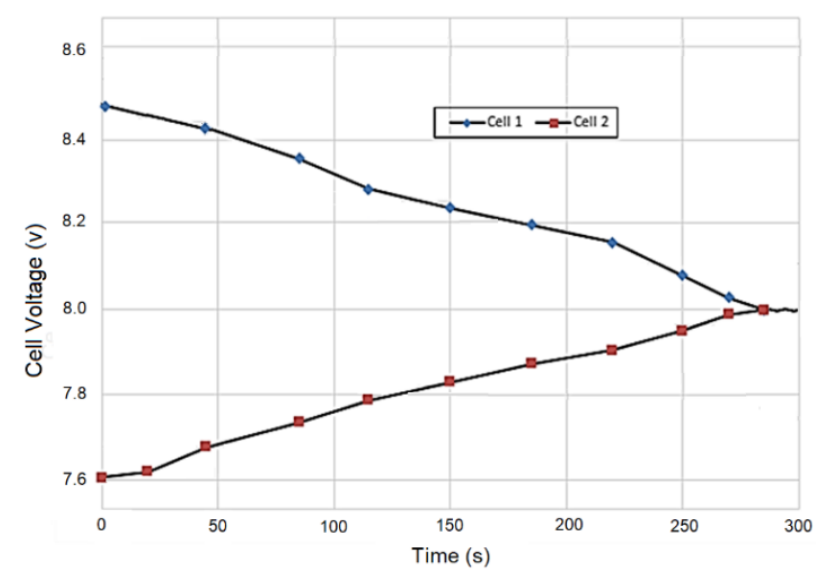

Fig. 10: The experimental result of the voltage balancing circuit.

\section{CONCLUSION}

The proposed design is a new topology of an active voltage balancing schemes for electrical energy storage devices. Due to the simple structure, it is able to quickly adjust the cells voltage difference of a battery pack. The proposed voltage balancing circuit requires few components to construct, which will reduce its size and contribute to reducing its price. It is a simple design, easy to build and can operate faster.

\section{ACKNOWLEDGMENT}

This research has been supported by the Malaysian Ministry of Education through the Fundamental Research Grant Scheme (FRGS) under the project ID: FRGS15-190-0431.

\section{REFERENCES}

[1] Iqbal H. (2011). Electric and Hybrid Vehicles: Design Fundamentals, CRC Press.

[2] Frost D. F., \& Howey D. A. (2018). Completely Decentralized Active Balancing Battery Management System. IEEE Transactions on Power Electronics, 33(1):729-738. 
[3] Yu Y., Saasaa R., \& Eberle W. (2016). A Series Resonant Circuit for Voltage Equalization of Series Connected Energy Storage Devices. Applied P Elec Conf and Exp (APEC) IEEE, 1286-1291.

[4] Rahman, A., Rashid, M., Mohiuddin, A. K. M., \& Hawlader, M. N. A. (2015). Nano-Battery Technology for EV-HEV Panel: A Pioneering Study. IIUM Engineering Journal, 16(2), 57-68.

[5] Li Y., \& Han Y. (2016). A Module-Integrated Distributed Battery Energy Storage and Management System. IEEE Trans P Elec., 31:8260-70.

[6] Mizanur R., Khan S., Hrairi M., Rahman A., \& Habib S. (2014). A Modularized Battery Charge Equalizer in the Application of Electric Vehicle. IEEE International Conference on Smart Instrumentation, Measurement and Applications (ICSIMA 2014).

[7] Gong X., Xiong R., \& Mi C. C. (2015). Study of the Characteristics of Battery Packs in Electric Vehicles with Parallel-Connected Lithium-ion Battery Cells. IEEE Trans. Ind. Appl., 51(2):1872-1879 Mar/Apr 2015.

[8] Hoque M. M., Hannan M. A., \& Mohamed A. (2016). Voltage Equalization Control Algorithm for Monitoring and Balancing of Series Connected Lithium-ion Battery. J Renewable Sustainable Energy, 8(2):1-15.

[9] Hoque M. M., Hannan M. A., Mohamed A., \& Ayob A. (2017). Battery Charge Equalization Controller in Electric Vehicle Applications: A Review. Renewable and Sustainable Energy Reviews, 75:1363-1385.

[10] Habib A. A., Motakabber S. M. A., \& Ibrahimy M. I. (2017). A Series Regeneration Converter Technique for Voltage Balancing of Energy Storage Devices. Indonesian Journal of Electrical Engineering and Computer Science, 8(2):475-481.

[11] Zhang Z., Gui H., Gu D. J., Yang Y., \& Ren X. (2017). A Hierarchical Active Balancing Architecture for Lithium-ion Batteries. IEEE Transactions on Power Electronics, 32(4):2757-2768.

[12] Li W., Liao X., \& Gao Z. (2016). A modular equalizer using buck/boost converters with snubber capacitors in series-connected supercapacitors. In Industrial Technology (ICIT), 2016 IEEE International Conference, 1904-1909. 